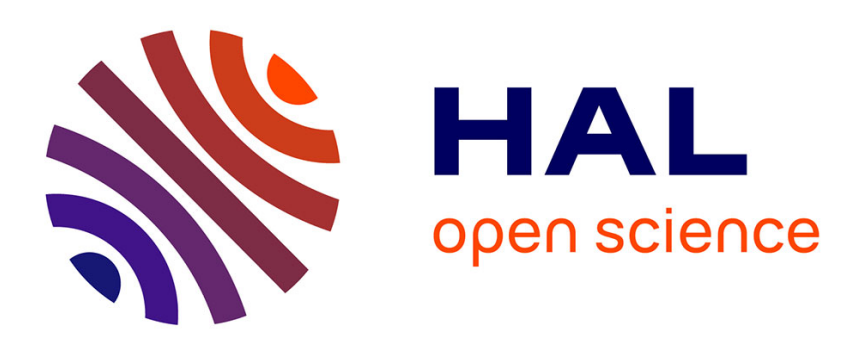

\title{
Genetic differentiation in Pinus brutia Ten. using molecular markers and quantitative traits: the role of altitude
}

Kurt, Santiago González-Martínez, Alía, Isik

\section{- To cite this version:}

Kurt, Santiago González-Martínez, Alía, Isik. Genetic differentiation in Pinus brutia Ten. using molecular markers and quantitative traits: the role of altitude. Annals of Forest Science, 2012, 69 (3), pp.345-351. 10.1007/s13595-011-0169-9 . hal-00930739

\section{HAL Id: hal-00930739 \\ https://hal.science/hal-00930739}

Submitted on 1 Jan 2012

HAL is a multi-disciplinary open access archive for the deposit and dissemination of scientific research documents, whether they are published or not. The documents may come from teaching and research institutions in France or abroad, or from public or private research centers.
L'archive ouverte pluridisciplinaire HAL, est destinée au dépôt et à la diffusion de documents scientifiques de niveau recherche, publiés ou non, émanant des établissements d'enseignement et de recherche français ou étrangers, des laboratoires publics ou privés. 


\title{
Genetic differentiation in Pinus brutia Ten. using molecular markers and quantitative traits: the role of altitude
}

\author{
Yusuf Kurt • Santiago C. González-Martínez • \\ Ricardo Alía · Kani Isik
}

Received: 9 May 2011 /Accepted: 15 November 2011 /Published online: 6 December 2011

(C) INRA / Springer-Verlag France 2011

\begin{abstract}
- Context Turkish red pine (Pinus brutia Ten.) is widespread in the eastern Mediterranean Basin. In the late 1970s, four common gardens were established along steep altitudinal transects extending from the coast to about $1,200 \mathrm{~m}$ in the Taurus Mountains (Antalya, Turkey).

- Aims The aim was to study the role of altitude in shaping Turkish red pine genetic diversity and population structure as well as to evaluate the existence of local adaptation along altitudinal gradients in this species.

- Methods Genetic diversity and population structure were evaluated in replicated altitudinal gradients using chloroplast microsatellite (cpSSR) markers. Genetic differentiation for neutral markers was compared with quantitative differentiation for growth traits for the same populations evaluated at different altitudes.

- Results Genetic differentiation among altitudinal groups was higher than among transects. A high portion of the genetic variance corresponded to families within populations (up to $10.75 \%$ ). Overall quantitative genetic differentiation $\left(Q_{\mathrm{ST}}\right)$ was higher than molecular differen-
\end{abstract}

Handling Editor: Luc Paques

Contribution of co-authors YK produced the molecular data, did data analyses, and wrote the paper; SCG-M contributed to the molecular data analyses and revised the paper; RA produced the quantitative genetics estimates; KI established the test sites, provided the raw quantitative data and revised the paper.

Y. Kurt $\cdot$ K. Isik $(\bowtie)$

Biology Department, Faculty of Sciences, Akdeniz University, 07058 Antalya, Turkey

e-mail: kani@akdeniz.edu.tr

Y. Kurt • S. C. González-Martínez • R. Alía

Department of Forest Ecology and Genetics, CIFOR-INIA,

P.O. Box 8111, 28080 Madrid, Spain tiation in most test sites for all the traits and ages considered.

- Conclusion Turkish red pine shows signatures of local adaptation to environmental gradients related to altitude. For forestry practices, such as selection of seed sources, both altitude and the family level of variation need to be considered.

Keywords Turkish red pine $\cdot$ Haplotypic variability $\cdot$ Local adaptation $\cdot$ Altitudinal variation $\cdot$ Genetic differentiation

\section{Introduction}

The ability of forest tree populations to evolve in response to environmental changes is crucial for their survival (Aitken et al. 2008). Consequently, the identification of those traits (and the underlying genes) linked to processes of adaptation to local environments has become a main goal for tree geneticists. Genetic differentiation for quantitative traits $\left(Q_{\mathrm{ST}}\right)$ is normally measured by computing the variance due to population differences in the metric trait investigated. This value can be compared with genetic differentiation for molecular markers, more specifically with the variance of allele frequencies among populations $\left(F_{\mathrm{ST}}\right)$. Neutral or quasineutral marker loci (as most microsatellites) are not affected by natural selection. Thus, they are expected to have a lower genetic differentiation than quantitative traits in the presence of local adaptation (Kremer et al. 2000; Leinonen et al. 2008; Whitlock 2008). Conversely, when $Q_{\mathrm{ST}}$ are significantly lower than $F_{\text {ST }}$, the action of stabilizing selection maintaining similar phenotypes can be depicted (e.g., Petit et al. 2001).

Estimates of genetic differentiation parameters for both quantitative traits and neutral markers are available in different forest trees (e.g., Yang et al. 1996; González-Martínez et al. 
2002; Ramírez-Valiente et al. 2009), showing that forest trees often have higher quantitative genetic differentiation levels than molecular ones. In most cases, this result has been interpreted as a local adaptation of populations and as the effect of selective forces acting differently on quantitative trait and molecular marker genetic diversity (GonzálezMartínez et al. 2002; Whitlock 2008).

Turkish red pine (Pinus brutia Ten.) is distributed in the eastern Mediterranean Basin naturally, mainly in the Mediterranean and Aegean regions of Turkey, with small isolated populations along the Black Sea coast. It covers 5.4 million hectares of forestland which constitutes $24 \%$ of the total forested areas in Turkey, and it is widely used in afforestation and reforestation programs (Boydak 2004; Anonymous 2006). Turkish red pine normally forms pure stands from sea level up to $1,500 \mathrm{~m}$ in the Taurus Mountains in the south and up to $600 \mathrm{~m}$ in the north. Natural stands are found on an extremely wide range of soil types and under a variety of climatic conditions. Turkish red pine shows regional adaptations along its large distribution range in Turkey, which makes it a relatively complex species. In the Taurus Mountains, a substantial amount of morphological variation seems to be a function of altitude and associated climatic factors (Isik et al. 1999; Isik and Isik 1999).

The main objective of this study was to investigate the role of altitude in promoting the differentiation of $P$. brutia populations using both molecular markers and quantitative traits and to test whether altitude is a relevant selective driver in this species. As altitude increases, the temperature and length of the growing season decrease, leading to a certain degree of phenological isolation and, potentially, to population adaptive divergence. However, this hypothesis has never been tested before, and whether previously observed morphological differences are due to selection, or to purely demographic or historical processes, is currently unknown. Thus, the specific objectives of this study were (1) to use highly polymorphic, paternally inherited chloroplast microsatellites (cpSSRs) to determine levels of neutral genetic variation and population genetic structure along steep altitudinal gradients; (2) to describe patterns of genetic differentiation using quantitative dataheight and diameter - obtained at different ages (reanalyzing data from previous work and including a new measurement at age 30); and (3) to compare molecular and quantitative data on the same populations and families to infer the role of altitude as a driver of local adaptation in this major pine species.

\section{Materials and methods}

\subsection{Common garden experiments}

The experimental setting of this study was established in 1979 with the general goal of studying quantitative genetic variation along altitudinal gradients for economically relevant traits in Turkish red pine. Six natural populations were sampled from two altitudinal transects extending from the Mediterranean coast to the Taurus Mountains in the Antalya region, in southern Turkey (see Isik et al. 1999). Three altitudinal classes were distinguished in each transect: coastal ( 100 ma.s.1.), middle range ( 500 ma.s.l.), and high elevations $(\sim 1,000$ ma.s.l.; see details in Table 1$)$. Selected stands had a natural origin (i.e., no plantations were included in the study) and had undergone similar management. Open-pollinated seeds were collected from a total of ten trees in each stand, and kept separate by parent tree. The seeds were first grown in a local nursery and then planted as $1+0$ seedlings in four common garden test sites located at different altitudes along the western transect in 1979 (Table 1). Each test site (set as completely randomized non-contiguous plots design) contained six populations, ten families per population, and 30 half-sib seedlings per family (see details in Isik et al. 1999; Isik and Isik 1999).

Height (in centimeters) and diameter (in millimeters) of trees were recorded at age 17 in Düzlercami and at age 18 in the other three test sites. More recently (in 2008), diameter was also measured at age 30 in Düzlercami and Kepez test sites. These latter data have never been presented before. Based on a previous linear model for age 17-18 (Isik et al. 1999), variance components were obtained by restricted maximum likelihood assuming similar genetic variances within populations. Then, the coefficient of genetic differentiation among populations $\left(Q_{\mathrm{ST}}\right)$ was estimated for each trait as:

$Q_{\mathrm{ST}}=V_{\mathrm{P}} /\left(V_{\mathrm{P}}+2 V_{\mathrm{A}}\right)$

where $V_{\mathrm{A}}$ is the additive genetic variance of a given trait within population and $V_{\mathrm{P}}$ is the genetic variance among populations. Standard errors were obtained using the Taylor series approximation (Gilmour et al. 2002). For diameter at age 30 , in addition to the overall $Q_{\mathrm{ST}}$, we were also able to compute the coefficient of population differentiation among altitudinal classes within transects and among transects in Düzlercami and Kepez test sites. Quantitative data were analyzed using SAS vs. 9.0 (SAS Institute Inc., Cary, NC).

\subsection{DNA extraction and cpSSR markers}

Needle samples for molecular analysis were collected (at Düzlercami test site) from 240 trees (60 half-sib families $\times$ four trees per family) belonging to the six populations included in the quantitative genetics multisite trial. The samples were stored at $-20^{\circ} \mathrm{C}$ until DNA extraction. Total genomic DNA was extracted from the needles using the Invisorb ${ }^{\circledR}$ DNA Plant HTS $96 \mathrm{Kit} / \mathrm{C}$. DNA concentrations were determined by electrophoresis on agarose gels and 
Table 1 Location of sampled P. brutia populations and common garden test sites (see also Isik et al. 1999)

\begin{tabular}{|c|c|c|c|c|c|}
\hline Transect & Code & Name & Altitude (m a.s.1.) & Latitude, $\mathrm{N}$ & Longitude, E \\
\hline \multicolumn{6}{|c|}{ Sampled populations } \\
\hline \multirow[t]{3}{*}{ Eastern } & $\mathrm{S}$ & Sarilar & 92 & $36^{\circ} 48^{\prime}$ & $31^{\circ} 26^{\prime}$ \\
\hline & M & Murtbeli & 490 & $37^{\circ} 01^{\prime}$ & $31^{\circ} 24^{\prime}$ \\
\hline & $\mathrm{K}$ & Kapan & 933 & $37^{\circ} 06^{\prime}$ & $31^{\circ} 24^{\prime}$ \\
\hline \multirow[t]{3}{*}{ Western } & $\mathrm{D}$ & Doyran & 61 & $36^{\circ} 52^{\prime}$ & $30^{\circ} 32^{\prime}$ \\
\hline & $\mathrm{B}$ & Buk & 480 & $36^{\circ} 58^{\prime}$ & $30^{\circ} 26^{\prime}$ \\
\hline & $\mathrm{H}$ & Hacibekar & 1,033 & $37^{\circ} 19^{\prime}$ & $30^{\circ} 11^{\prime}$ \\
\hline \multicolumn{6}{|c|}{ Common garden test sites } \\
\hline \multirow[t]{4}{*}{ Western } & 1 & Kepez & 90 & $36^{\circ} 55^{\prime}$ & $30^{\circ} 36^{\prime}$ \\
\hline & 2 & Düzlercami & 350 & $36^{\circ} 58^{\prime}$ & $30^{\circ} 32^{\prime}$ \\
\hline & 3 & Buk & 500 & $36^{\circ} 57^{\prime}$ & $30^{\circ} 25^{\prime}$ \\
\hline & 4 & Yenicedere & 850 & $37^{\circ} 01^{\prime}$ & $30^{\circ} 25^{\prime}$ \\
\hline
\end{tabular}

comparisons with standards of known concentration. Six primer pairs for chloroplast microsatellites (Vendramin et al. 1996) were used: Pt1254, Pt15169, Pt30204, Pt36480, Pt71936, and Pt87268.

PCR amplifications were carried out in a total volume of $10 \mu$ containing $5 \mathrm{ng}$ of template DNA, $2 \mathrm{mM} \mathrm{MgCl}$, $0.2 \mu \mathrm{l}$ BSA $(10 \mathrm{mg} / \mathrm{ml}), 1 \times$ reaction buffer (Ecogen, Barcelona, Spain; Invitrogen, the Netherlands), $1.5 \mathrm{pmol}$ reverse primer, 1.5 pmol forward primer labeled with IRD800, and 0.4 U Taq polymerase (Ecogen and Invitrogen). Reactions were carried out on a Perkin Elmer 9700 thermal cycler (Applied Biosystems Norwalk, CT, USA) using the following parameters: initial denaturation at $95^{\circ} \mathrm{C}$ for $5 \mathrm{~min}$, followed by $15-30$ cycles of $1 \mathrm{~min}$ at $94^{\circ} \mathrm{C}, 45 \mathrm{~s}$ at $55^{\circ} \mathrm{C}$, and $1 \mathrm{~min}$ at $72^{\circ} \mathrm{C}$, and a final extension step of $8 \mathrm{~min}$ at $72^{\circ} \mathrm{C}$. Amplification products were resolved on $7 \%$ denaturing polyacrylamide gels $(25 \mathrm{~cm}$ long, $0.25 \mathrm{~mm}$ thick). Electrophoresis was performed in Li-Cor 4300 automated sequencers (Li-Cor Bioscience Lincon, Nebraska, USA) using $0.8 \times \mathrm{TBE}$ running buffer at $1,500 \mathrm{~V}, 40 \mathrm{~mA}$, and $45^{\circ} \mathrm{C}$ of plate temperature. Samples were loaded with external standards in the same gel.

\section{$2.3 \mathrm{cpSSR}$ data analysis}

Haplotypes were defined as a unique combination of size variants across the six microsatellite regions. Standard haplotypic Nei's genetic diversity $\left(H_{\mathrm{e}}\right)$ was computed using custom spreadsheets. Genetic diversity according to a microsatellite stepwise mutation model (SMM) was estimated using the average genetic distance among individuals within populations, $D_{\mathrm{sh}}^{2}$, as defined by Vendramin et al. (1998). This distance considers the pairwise differences in repeat units at the SSRs for all individuals in a sample (Goldstein et al. 1995).

To estimate neutral genetic differentiation, analysis of molecular variance (AMOVA) was used. Different hierarchi- cal AMOVAs based on altitudes and transects were computed using Arlequin version 3.1 (Excoffier et al. 2005), calculating in every case $F_{\mathrm{ST}}$ and $R_{\mathrm{ST}}$ coefficients of population differentiation. $F$ statistics are classical estimates of genetic differentiation that only take into account haplotype frequencies, while $R$ statistics also incorporate haplotype distances following a SMM in the calculations. The comparison of these two indices, which are estimated from the same cpSSR data, can provide useful information on the causes of population differentiation, in particular about the existence of a phylogeographic structure (Hardy et al. 2003). Finally, we performed Bayesian analyses of population structure using BAPS vs. 4.14 (Corander et al. 2003) to test for population clustering with no prior assumptions of population differentiation.

\section{Results}

\section{1 cpSSR genetic diversity and differentiation}

All primers, except Pt36480, were polymorphic. The six primers altogether yielded a total of 29 variants (from one variant in monomorphic Pt36480 to nine in Pt1254) in a set of 231 individuals from six different populations (9 samples out of 240 failed to amplify). The chloroplast microsatellite (cpSSR) variants were combined in 60 different haplotypes. The cpSSR variants showed single 1-bp mutational steps, except for Pt71936 in which a 2-bp gap was detected. This gap was found in 13 individuals in all populations except Sarilar. There were only four shared haplotypes among all populations (H12, H19, H39, and H45). The frequency of these haplotypes was $45.5 \%$ overall. Thirty-seven $(61.7 \%)$ out of the 60 haplotypes were private (i.e., unique) to one population. On average, $10.3 \%$ of the haplotypes found in each population were private.

The overall mean genetic diversity was very high, 0.9283 (ranging from 0.8667 in Murtbeli to 0.9582 in Sarilar; Table 2). 
The average mean genetic distance among individuals within populations $\left(D_{\mathrm{sh}}^{2}\right)$ was 4.87 . Overall genetic differentiation among populations, as estimated by $F_{\mathrm{ST}}$, was 0.0122 . Judging by the AMOVAs, the genetic differentiation among altitudinal classes was low for estimates based on haplotype frequency $\left(F_{\mathrm{ST}}\right)$, but significant for estimates based on the $\mathrm{SMM}\left(R_{\mathrm{ST}}=\right.$ 0.0497; Table 3), indicating that altitudinal differences produced some phylogeographical structure. Similar results were obtained from the altitude component of hierarchical AMOVAs by transect (albeit in this case $F_{\mathrm{ST}}$ was significantly different from zero; Table 3). Genetic differentiation among transects was negligible despite much longer distances among transects than among populations at different altitudes within transects. In addition, a significant portion of the genetic variation was found among families within populations (3.55-10.75\%, see Table 3). Finally, BAPS Bayesian clustering singled out the high-altitude Hacibekar population, while the rest were pooled together. Nevertheless, running hierarchical AMOVAs removing this population did not change the results (not shown).

\subsection{Quantitative genetic variation and comparison} with molecular markers

P. brutia showed relatively high levels of genetic differentiation among populations $(0.065-0.384)$ for height and diameter at age 17-18 in the four test sites (Table 4). $Q_{\mathrm{ST}}$ differentiation values for these traits (in Table 4) were always higher than the neutral genetic differentiation among populations, as shown by cpSSRs (in Table 3). However, large standard errors and contrasting values of the coefficient of quantitative differentiation across test sites were observed for diameter at age 30 (Table 4). For this trait, although overall quantitative genetic differentiation was still higher than the molecular one (in Table 3), $Q_{\mathrm{ST}}$ among altitudinal classes varied from none (Düzlercami test) to a very high value of $41 \%$ (Kepez test).

Table 2 Genetic diversity estimates based on six cpSSRs (combined in haplotypes) for six Turkish red pine populations from Antalya region

\begin{tabular}{llllll}
\hline Population code & $n$ & $N$ & $N_{\mathrm{p}}$ & $H_{\mathrm{e}}$ & $D_{\mathrm{sh}}^{2}$ \\
\hline S & 39 & 24 & 8 & 0.9582 & 4.03 \\
M & 40 & 16 & 3 & 0.8667 & 4.37 \\
K & 38 & 20 & 7 & 0.9403 & 5.94 \\
D & 40 & 23 & 6 & 0.9538 & 4.21 \\
B & 39 & 21 & 3 & 0.9514 & 4.68 \\
H & 35 & 17 & 10 & 0.8992 & 5.97 \\
Average & 38.5 & 20.2 & 6.2 & 0.9283 & 4.87 \\
\hline
\end{tabular}

$n$ number of individuals analyzed, $N$ number of haplotypes, $N_{\mathrm{p}}$ number of private haplotypes, $H_{\mathrm{e}}$ Nei's gene diversity, $D_{\mathrm{sh}}^{2}$ average stepwise genetic distance among haplotypes within populations

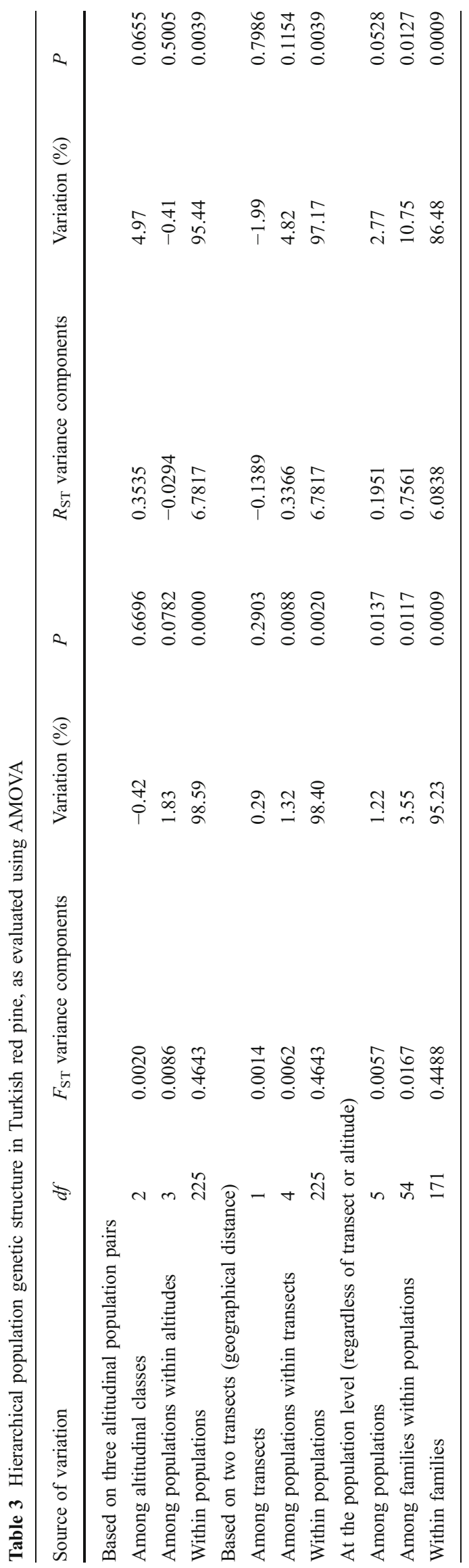


Table 4 Coefficient of quantitative differentiation $\left(Q_{\mathrm{ST}}\right)$ for total height at age 17-18 (H18) and diameter at age 17-18 (dbh18) and 30 in four test sites located at different altitudes along two transects in the Antalya region

\begin{tabular}{|c|c|c|c|c|c|c|}
\hline \multirow[t]{2}{*}{ Test site } & \multirow[t]{2}{*}{ Altitude (m a.s.1.) } & \multicolumn{2}{|c|}{ Age $17-18$} & \multicolumn{3}{|l|}{ Age 30 (diameter) } \\
\hline & & $\mathrm{H} 18$ & $\mathrm{dbh} 18$ & Overall & By altitudinal classes & By transects \\
\hline Kepez & 90 & 0.095 & 0.214 & $0.396( \pm 0.270)$ & $0.410( \pm 0.459)$ & $0.000(\mathrm{NA})$ \\
\hline Düzlercami & 350 & $0.170^{\mathrm{a}}$ & $0.119^{\mathrm{a}}$ & $0.077( \pm 0.1346)$ & 0.000 (NA) & $0.077( \pm 0.1346)$ \\
\hline Buk & 500 & 0.281 & 0.384 & NA & NA & NA \\
\hline Yenicedere & 850 & 0.182 & 0.065 & NA & NA & NA \\
\hline
\end{tabular}

For diameter at age 30, estimates are given for overall differentiation (regardless of altitudinal classes and transects) and for differentiation among altitudinal and transect groups. Standard errors in parenthesis

$N A$ not applicable as measurements for these two sites were not available

${ }^{\text {a }}$ Measurement at age 17

\section{Discussion}

General levels of cpSSR genetic diversity $\left(H_{\mathrm{E}}=0.9283\right.$ and $\left.D_{\mathrm{sh}}^{2}=4.87\right)$ were very high in Turkish red pine, despite the limited sampling, and similar to or slightly higher than in other European pines (sampled in a wider range): for example, $D_{\mathrm{sh}}^{2}$ of 3.58 for Pinus halepensis (Morgante et al. 1998) and of 4.3 for Pinus sylvestris (Robledo-Arnuncio et al. 2005). In comparison with the study of Bucci et al. (1998) on Turkish red pine, we found a substantially higher within-population haplotypic diversity, probably due to the much larger sampling size per population in our study (about five fold). Such high levels of haplotypic diversity in Turkish red pine may respond to more stable effective population sizes in eastern Mediterranean forest tree populations, as recently suggested for Aleppo pine by Grivet et al. (2009) and, more in general, for Mediterranean conifers by Fady (2005). Finally, our study indicates that cpSSR markers could be useful to monitor genetic diversity changes in Turkish red pine populations due to their high resolution and easy optimization for different genotyping platforms.

Neutral genetic differentiation in P. brutia was low (albeit significant), yet within the range previously reported for this species using isozyme and RAPD markers (e.g., Kara et al. 1997; Lise et al. 2007). The Bayesian clustering analysis (BAPs) revealed that the Hacibekar population is highly differentiated from the others. Hacibekar also showed the highest number of private haplotypes (58.8\%). This population is noteworthy because it is located over an altitude of $1,000 \mathrm{~m}$, which is close to the altitudinal limit of the species, on a transition region between Mediterranean and continental climates. Ecological marginality could have contributed to the isolation and accumulation of new mutations over time.

Interestingly, in our study, larger genetic differences (as estimated with cpSSRs, a paternally inherited marker) were found for Turkish red pine as a function of altitude than as a function of distance between transects. As a higher $R_{\mathrm{ST}}$ than $F_{\mathrm{ST}}$ has been found, these differences can be interpreted as the development of local lineages (i.e., the existence of a phylogeographic structure). The results also hold when the marginal population of Hacibekar is removed from the analyses. In contrast, several other studies using molecular markers have reported lack of genetic differentiation along altitudinal gradients in pines. For instance, Navascués et al. (2008) found very low genetic differentiation in Pinus canariensis along altitudinal gradients using chloroplast and nuclear microsatellites, and Saenz-Romero and Tapia-Olivares (2003) have reported no significant genetic differentiation with altitude in Pinus oocarpa using allozymes.

Genetic differentiation with altitude is even more notable when considering quantitative traits (e.g., $Q_{\mathrm{ST}}$ from 0.065 to 0.384 at age $17-18$ ). Although information about genetic differentiation along altitudinal gradients based on common gardens is very scarce, altitudinal variation of some morphological traits has been reported in Turkish red pine (e.g., Dangasuk and Panetsos 2004) as well as in other forest trees (e.g., Saenz-Romero et al. 2006; Alberto et al. 2011). Differentiation along altitudinal gradients in quantitative traits can be explained by phenological or ecological isolation and selective pressure resulting in genetic clines (Ohsawa and Ide 2008).

Quantitative genetic differentiation $\left(Q_{\mathrm{ST}}\right)$ varied depending on the site considered, suggesting a certain level of phenotypic plasticity in Turkish red pine (Table 4). However, large standard errors in the estimates make this result inconclusive, and further studies are needed to support this finding. The $Q_{\mathrm{ST}}$ values for total height were generally higher at the sites located at middle altitude (for example, at Buk site located at 500 ma.s.1.), which coincides with the core range of the species. Nevertheless, with respect to diameter at age 30, significant genetic differentiation along the altitudinal gradient was found only at the lower altitude test site (Kepez, 90 ma.s.l.). These results are relevant for the adaptive response of Turkish red pine to climatic 
change as it is expected that populations will be subject to altitudinal shifts in the next decades.

The overall picture suggests that Turkish red pine has higher levels of quantitative than of molecular genetic differentiation. Different studies have reported similar results in a wide range of organisms (see reviews in Kremer et al. 2000; Latta 2004; Leinonen et al. 2008), including forest trees (e.g., Yang et al. 1996; González-Martínez et al. 2002, 2004). In most cases, such results have been interpreted as selective forces acting differentially on quantitative traits and on molecular markers (Whitlock 2008). In the particular case of altitudinal gradients, a steep clinal variation in environmental factors, such as temperature and precipitation, may have led to local adaptation despite substantial gene flow among populations. González-Martínez et al. (2002) suggested that environmental heterogeneity and genotype-byenvironment interactions have major roles in quantitative differentiation in maritime pine, a Mediterranean pine species with great dispersal ability. This could also be the case in Turkish red pine from the Taurus Mountains.

\section{Conclusions}

This study provides new data concerning the genetic diversity of Turkish red pine, both with cpSSR markers and quantitative traits. Turkish red pine populations have a high level of genetic variation. Genetic diversity, in particular at quantitative traits, is more associated with seed source elevation than with geographical proximity between Turkish red pine populations in the Antalya region. In addition, our analyses using cpSSRs showed higher levels of variation within families than among populations. Therefore, for forestry practices such as selection of seed sources, determination of seed transfer zones, and genetic resource conservation programs, both altitudinal gradients and family level of variation must be considered. It is important to note that this study is based on only a small part of the species' distribution range. In view of the high levels of variation found between and within populations, higher numbers of stands (and families), covering a wider range of environments and altitudinal gradients, should be systematically studied for further population genetic analysis, including both molecular and quantitative traits.

Acknowledgments This study was supported by Akdeniz University Scientific Research Projects Unit (project no. 2008.03.0121.006) and projects from the European Union (EVOLTREE Network of Excellence, http://www.evoltree.eu) and the Spanish Ministry of Environment (CC03-048 and AEG06-054). The Scientific and Technical Research Council of Turkey (TUBITAK)-BIDEB/BDP program granted a research scholarship to Yusuf KURT while studying at CIFOR-INIA. Thanks are also extended to P.C. Grant, science editor.

\section{References}

Aitken SN, Yeaman S, Holliday JA, Wang T, Curtis-McLane S (2008) Adaptation, migration or extirpation: climate change outcomes for tree populations. Evol Appl 1:95-111

Alberto F, Bouffier L, Louvet JM, Delzon S, Kremer A (2011) Adaptive responses for seed and leaf phenology in natural populations of sessile oak along altitudinal gradients. J Evol Biol 24:1442-1454

Anonymous (2006) Forest Assets of Turkey. Forestry Directorate of Turkey. Ankara, p 160

Boydak M (2004) Silvicultural characteristics and natural regeneration of Pinus brutia Ten.- - review. Plant Ecol 171:153-163

Bucci G, Anzidei M, Madaghiele A, Vendramin GG (1998) Detection of haplotypic variation and natural hybridization in halepensiscomplex pine species using chloroplast simple sequence repeat (SSR) markers. Mol Ecol 7:1-11

Corander J, Waldmann P, Sillanpaa MJ (2003) Bayesian analysis of genetic differentiation between populations. Genetics 163:367-374

Dangasuk OG, Panetsos KP (2004) Altitudinal and longitudinal variations in Pinus brutia (Ten.) of Crete Island, Greece: some needle, cone and seed traits under natural habitats. New Forest 27:269-284

Excoffier L, Laval G, Schneider S (2005) Arlequin ver. 3.0: an integrated software package for population genetics data analysis. Evol Bioinform Online 1:47-50

Fady B (2005) Is there really more biodiversity in Mediterranean forest ecosystems? Taxon 54:905-910

Gilmour AR, Cullis BR, Welham SJ, Thompson R (2002) ASREML reference manual, NSW Agriculture, Orange

Goldstein DB, Ruiz LA, Cavalli-Sforza LL, Feldman MW (1995) An evolution of genetic distances for use with microsatellite loci. Genetics 139:463-471

González-Martínez SC, Alía R, Gil L (2002) Population genetic structure in a Mediterranean pine (Pinus pinaster Ait.): a comparison of allozyme markers and quantitative traits. Heredity 89:199-206

González-Martínez SC, Mariette S, Ribeiro MM, Burban C, Raffin A, Chambel MR, Ribeiro CAM, Aguiar A, Plomion C, Alía R, Gil L, Vendramin GG, Kremer A (2004) Genetic resources in maritime pine (Pinus pinaster Aiton): molecular and quantitative measures of genetic variation and differentiation among maternal lineages. Forest Ecol Manag 197:103-115

Grivet D, Sebastiani F, González-Martínez SC, Vendramin GG (2009) Patterns of polymorphism resulting from long-range colonization in the Mediterranean conifer Aleppo pine. New Phytol 184: $1016-1028$

Hardy OJ, Charbonnel N, Fréville H, Heuertz M (2003) Microsatellite allele sizes: a simple test to assess their significance on genetic differentiation. Genetics 163:1467-1482

Isik K, Isik F (1999) Genetic variation in Pinus brutia Ten. in Turkey II. Branching and crown traits. Silvae Genet 48:293-302

Isik F, Isik K, Lee SJ (1999) Genetic variation in Pinus brutia Ten. in Turkey I. Growth, biomass and stem quality traits. For Genet 6:89-99

Kara N, Korol L, Isik K, Schiller G (1997) Genetic diversity in Pinus brutia Ten.: altitudinal variation. Silvae Genet 46:155-161

Kremer A, Le Corre V, Mariette S (2000) Population differentiation for adaptive traits and their underlying loci in forest trees: theoretical predictions and experimental results, vol 63. In: Matyas C (ed) Forest genetics and sustainability. Kluwer Academic, Dordrecht, pp 59-74

Latta RG (2004) Relating processes to patterns of genetic variation across landscapes. Forest Ecol Manag 197:91-102

Leinonen T, O'Hara R, Cano JM, Merila J (2008) Comparative studies of quantitative trait and neutral marker divergence: a meta-analysis. J Evol Biol 21:1-17 
Lise Y, Kaya Z, Isik F, Sabuncu R, Kandemir I, Onde S (2007) The impact of over-exploitation on the genetic structure of Turkish red pine (Pinus brutia Ten.) populations determined by RAPD markers. Silva Fenn 41:211-220

Morgante M, Felice N, Vendramin GG (1998) Analysis of hypervariable chloroplast microsatellites in Pinus halepensis reveals a dramatic bottleneck. In: Karp A, Isaac PG, Ingram DS (eds) Molecular tools for screening biodiversity: plants and animals. Chapman and Hall, London, pp 407-412

Navascués M, Vendramin GG, Emerson BC (2008) The effect of altitude on the pattern of gene flow in the endemic Canary Island Pine, Pinus canariensis. Silvae Genet 57:357-363

Ohsawa T, Ide Y (2008) Global patterns of genetic variation in plant species along vertical and horizontal gradients on mountains. Global Ecol Biogeogr 17:152-163

Petit C, Fréville H, Mignot A, Riba M, Colas B, Imbert E, Bousses-Hurtrez S, Virevaire M, Olivieri I (2001) Gene flow and local adaptation in two endemic plant species. Biol Conserv 100:21-34

Ramírez-Valiente JA, Lorenzo Z, Soto A, Valladares F, Gil L, Aranda I (2009) Elucidating the role of genetic drift and directional natural selection in genetic differentiation of cork oak (Quercus suber L.). Mol Ecol 18:3803-3815
Robledo-Arnuncio JJ, Collada C, Alía R, Gil L (2005) Genetic structure of montane isolates of Pinus sylvestris L. in a Mediterranean refugial area. J Biogeogr 32:595-605

Saenz-Romero C, Tapia-Olivares BL (2003) Pinus oocarpa isoenzymatic variation along an altitudinal gradient in Michoacan, Mexico. Silvae Genet 52:237-240

Saenz-Romero C, Guzman-Reyna RR, Rehfeldt GE (2006) Altitudinal genetic variation among Pinus oocarpa populations in Michoacan, Mexico. Implications for seed zoning, conservation, tree breeding and global warming. Forest Ecol Manag 229:340-350

Vendramin GG, Lelli L, Rossi P, Morgante M (1996) A set of primers for the amplification of 20 chloroplast microsatellites in Pinaceae. Mol Ecol 5:595-598

Vendramin GG, Anzidei M, Madaghiele A, Bucci G (1998) Distribution of genetic diversity in Pinus pinaster Ait. as revealed by chloroplast microsatellites. Theor Appl Genet 97: 456-463

Whitlock MC (2008) Evolutionary inference from $Q_{\mathrm{ST}}$. Mol Ecol 17:1885-1896

Yang RC, Yeh FC, Yanchuk AD (1996) A comparison of isozyme and quantitative genetic variation in Pinus contorta ssp. latifolia by $F_{\text {ST. }}$ Genetics 142:1045-1052 